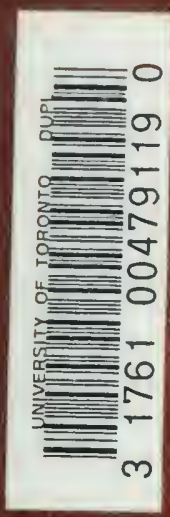

(G)

1.

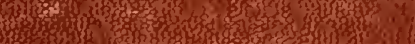

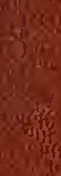
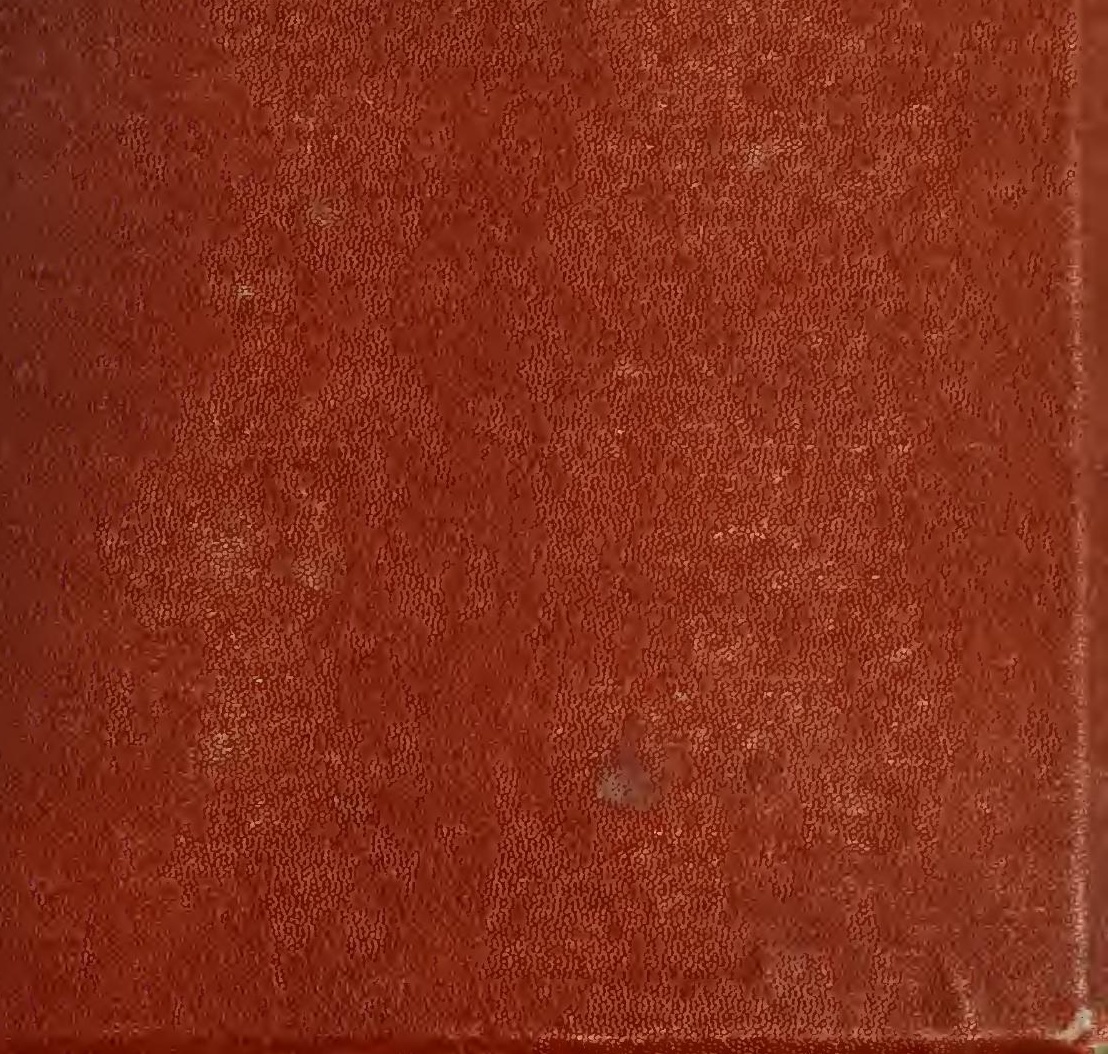

H. W 
PRESENTED

To

The University of Toronto

IiY

Columbia College

NEW TORK

OCTOBEF 2IST, 1890 


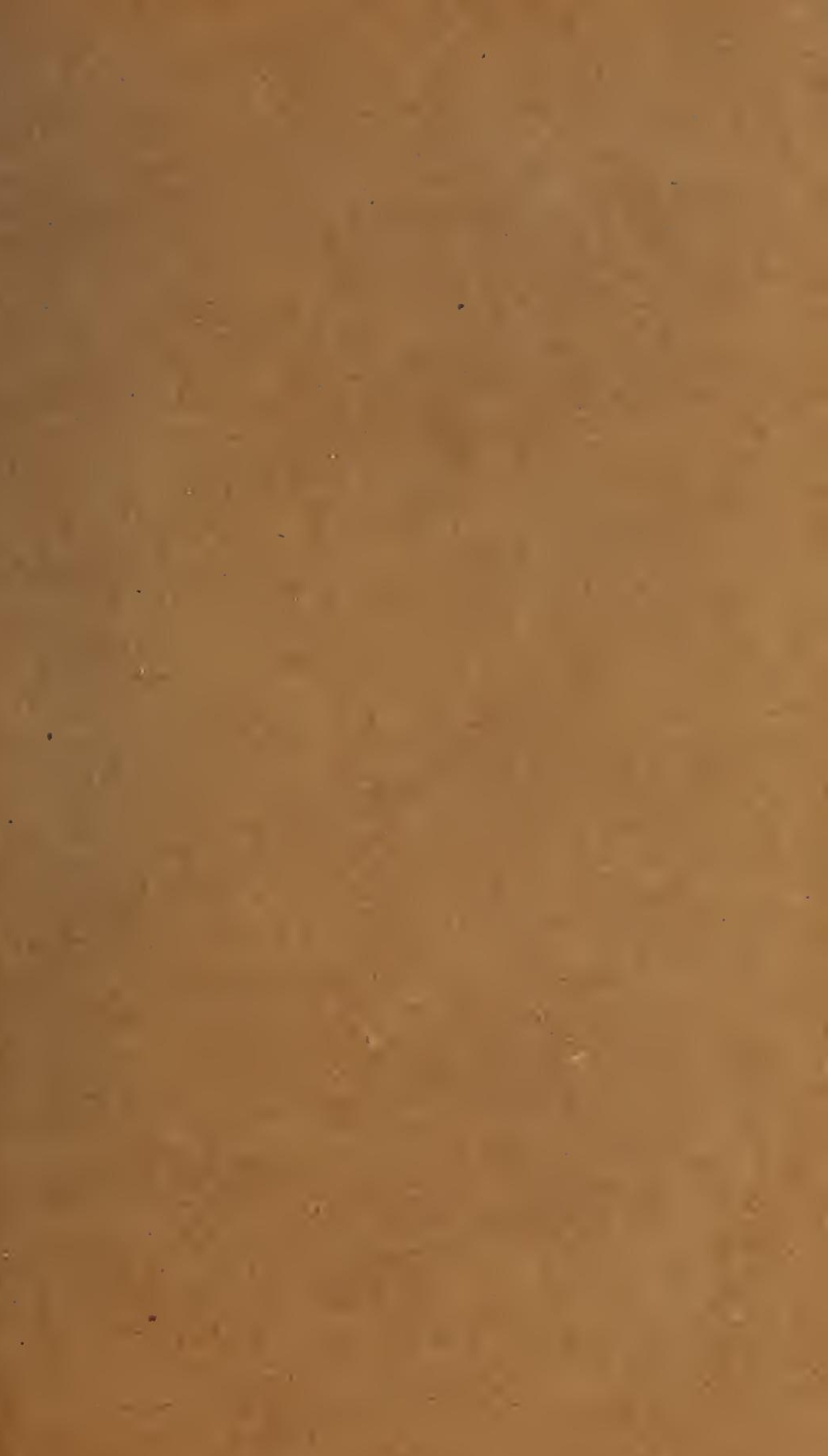





$$
\frac{3}{5 i}: 3.2
$$


Digitized by the Internet Archive in 2008 with funding from Microsoft Corporation 


\title{
LOVE'S MEINIE.
}

\author{
LECTURES
}

oN

\section{GREEK AND FNGLISH BIRDS.}

GIVEN BEFORE THE UNIVERSITY OF OXFORD.

BY

$$
\text { JOHN RLSKIX, LL.D., }
$$

HOXORARY STLDENT OF CHRISTCHCRCH, AND SLADE PROFESSOR OF FINE ART.

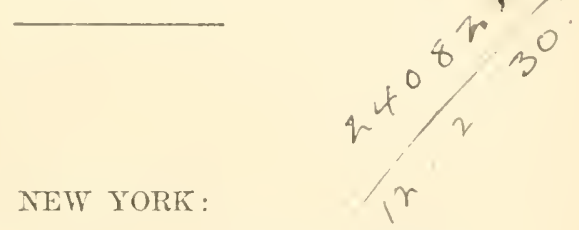

JOHN WILEY \& SON, 15 ASTOR PLACE. $18 \pi 3$. 


$$
\begin{aligned}
& Q L \\
& 876 \\
& \text { P87 }
\end{aligned}
$$




\section{A D VICE.}

I PCBLIsI these lectures at present roughly, in the form in which, they were delivered,- - necessarily more brief and broken than that which may be permitted when time is not limited.) - hecanse I know that some of their hearers wished to olstain them for immediate reference. Ultimately, I hope, they will he completed in an illustrated rolume, containing at least six lectures, on the Robin, the Swallow, the C'hough, the Jark, the Swan, and the Sea-gull. But months pass by me now, like days: and my work remains only in design. I think it better, therefore, to let the lectures appear separately. with provisional wood-cuts, afterwares to be bettered, or replaced by more finished engrarings. The illustrated volume. if ever finislierl, will cost a grinea; but these separate lectures a slilling, or, if long, one shilling and sixpence each. The guinen's worth will, perhaps, be the cheaper book in the end; but I slatl be glad if some of $\mathrm{m}$ hearers felt interest enough in the subject to prevent their waiting for it.

The modern vulgarization of the word "advertisement " renclers, I think, the use of 'advice' as abore, in the sense of the French 'aris' (passing into our old English rerl, 'arise') on the whole, preferable.

BrastwoOd,

June, 18 is. 



\title{
LOVE'S MEINIE.
}

"Il etoit tout couvert d'oisiaulx."

Romaje of tire Rose.

\section{LECTURE I.}

\author{
THE ROBIN.
}

1. Arong the more splendid pictures in the Exhibition of the Old Masters, this year, you camnot but remember the Tandyke portraits of the two sons of the Duke of Jemnox. I think you cannot but remember it, because it would be difficult to find, even among the works of Tandyke, a more striking representation of the youth of our English noblesse; nor one in which the painter had more exerted himself, or with better success, in rendering the decorous pride and natural grace of honourable aristocracy.

Tandyke is, horrever, inferior to Titian and Velasquez, in that his effort to show this noblesse of air and persons may always be detecterl; also the aristeracy of Tandylie's day were already so far fearful of their own position as to feel anxiety that it should be immediately reeognized. And the effect of the painter's conscions defer- 
ence, and of the equally conscions pride of the boys, as they stood to be painted, has been somewhat to shorten. the power of the one, and to abase the dignity of the other. And this, in the midst of $n y$ admiration of the Jonths' heantiful faces, and natural quality of majesty, set off $b y$ all splendours of dress and courtesies of art, I conlt not forbear questioning with myself what the true value was, in the scales of creation, of these fair human beings who set so high a vahne on themselves; and.-as if the only answer,-the words kept repeating themselres in my ear, "Ye are of more value than many sparrows."

2. Passeres, orpovtou,-the things that open their wings, and are not otherwise noticeable; small bircts of the land and rood; the foud of the serpent, of man, or of the stronger creatures of their own kind,--that even these, thomgh among the simplest and obscurest of beings, have yet prive in the eyes of their Maker, and that the death of one of them cannot take place but by II permission, has lom heen the subject of declamation in our pulpits, and the ground of much sentiment in nursery education. But the declamation is so aimless, and the sentiment so hollow, that, practically, the chief interest of the leismre of mankind has been fomd in the destruction of the creatures which they professed to believe eren the Mrost Migh wonld not see perish withont pity; and, in recent days, it is fast becoming the only definition of aristocraey, that the principal business of its life is the killing of sparrows. sjarrows, or pigeons, or partridges, what does it mat- 
ter" "Centum mille perdrices plumbo confecit;" * that is, indeed, too often the sum of the life of an English lord; much questionalule nuw, if indeed of more value thim that of many sparrows.

3. Is it not a strange fact, that, interested in nothing so much for the last two humdred years, as in his lorses, he yet left it to the farmers of Scotland to relieve dranght horses from the bearing-rem; $\dagger$ is it not one equally strange that, master of the forests of England for a thousand years, and of its libraries for three hmudred, he left the natural history of birds to be written by a card-printer's lad of Newcastle? Written, and not written, for indeed we have no natmul history of birds written yet. It cannot be written bnt lyy a scholar and a gentlenan; and no English gentleman in recent times has erer thought of birds except as flying targets, or flavomrous dishes. The only piece of natural history worth the name in the English langnage, that I know of, is in the few lines of Milton on the Creation. The only example of a proper manner of contribation to natural history is in White's Letters from Selborne. You know I have always spoken of Bewick as pre-eminently a volgar or hoorish person, though of splendid honom and genius; his vulgarity shows in nothing so much as in the poverty of the details he has eollected, with the best intentions, and the shrewdest

* The epitaph on Count Zachdarm, in "Sartor Resartus"

+ Sir Arthur Helps. " Animals and their Masters," 1. 67. 
sense, for English ornithology. His imagination is not (*nltivated enongh to enable him to choose, or arrange.

4. Nor can much more be said for the observations of modern science. It is rulgar in a far worse way, by its arrogance and materialism. In general, the scientific matmal history of a bird consists of forr articles,--first, the name and estate of the gentleman whose gamekeeper shot the last that was seen in England; secondly, two or three stories of doubtful origin, printed in every book on the subject of birds for the last fifty years; thirdly, an account of the feathers, from the comb to the rump, with entmeration of the colours which are never more to be seen on the living bird by English eyes; and, lastly, a discussion of the reasons why none of the twelve names which former naturalists have given to the bird are of any further nse, and why the present anthor has giren it a thirteenth, which is to be universally, and to the end of lime, accepted.

5. Ion may fancy this is carieature; but the abyss of confusion prodnced by moderu science in nomenclature, and the utter roid of the abyss when you plunge into it after any ome nseful fact, surpass all caricature. I have in my hand thirteen plates of thirteen species of eagles; eagles all, or hawks all, or falcons all-whicherer name you choose for the great race of the hook-headed birds of prey-some so like that you can't tell the one from the other, at the distance at which I show them to you, all absolutely alike in their eagle or falcon character, haring, 
every one, the falx for its beak, and every one, flesh fur its prey. Do you suppose the mluapy student is to be allowed to call them all eagtes, or all falcons, to begin with, as woukd be the first condition of a wise nomenclature, establishing resemblance h, specific name, beforo marking variation by individual name! No snch luck. I hold yon up the plates of the thirteen birds one lyy one, and read you their names off the back:-

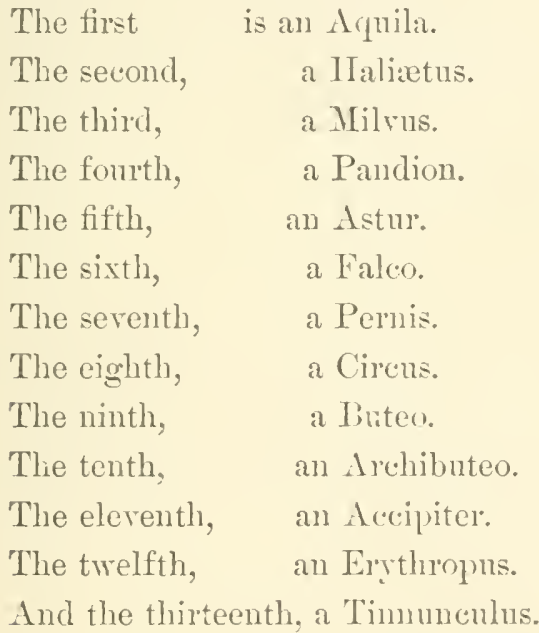

There's a nice little lesson to entertain a parish schoolboy with, begimning his natural history of birds!

6. There are not so many rarieties of robin as of haw-k, but the scientific classifiers are not to be beaten. If they camnot find a number of similar birds to give liflerent names to, they will gire tro names to the same one. Here are two pietures of your own redbreast, ont of the $1 *$ 
two best modern works on ornithology. In one, it is called "Mrtacilla rubecula;" in the other, "Pinbecula fimiliaris."

7. It is indeed one of the most scrious, as one of the most absurd, weaknesses, of modern naturalists to imagine that any presently invented nomenclature can stand, eren were it adopted by the consent of nations, instead of the conceit of individuals. It will take fifty rears' digestion before the recently ascertained elements of natural science can permit the arrangement of species in any permanently (eren orer a limited period) nameable order; nor then, muless a great man is born to perceive and exhibit such order. In the meantime, the simplest and most descriptive nomenclature is the best. Every one of these birds, for instance, might be called falco in Latin, hawk in English, some word being added to distinguish the genus, which shonld deseribe its principal aspect or habit. Falco montium, Hountain Hawk: Faleo silvarum, Wood Hawk; Faleo procellarm. Sea Mawk: and the like. Then, one descriptive epithet would mark species. Falco montium, aurens, Golden Eagle; Faleo silvarum, apirorus. IIones Buzzard: and so on: and the naturalists of Viemna, Paris, and London should confirm the nanes of known creatures, in conclave, once every lualf century, and let them so stand for the next fifty years.

S. In the meantime, you poursulves, or. to speak more generally, the young rising scholars of England,-all of you who care for life as well as literature, and for 
spirit,-even the pour souls of birds,-as well as lettering of their ('lasses in bouks,-rou, with all (are, fhould wher-

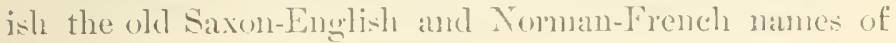
birds, and ascertain then with the nost affectionate research-never despising even the rudest or nust provincial forms: all of them will, some day or other, grive you che to historjual points of interest. Talie, for example, the common English name of this low-flying falcem, the most tancalole and affectionate of his tribe, and thesefore, I suppose, fastest vanisling from field and woorl, the bnzzard. That name comes from the Latin "Luter," still retained by the ornitholocists: but, in its original form, valneless, to you. But when you get it comfortably corrupterl into Provençal "Busac," (whence graulually the French husard, and our buzzard,) you get from it the delightful compound "busacador;" "adorer" of luzzards" -meaning, generally, a sporting person; and then gon have Dante's Bertrand de Borm, the first troulualour of war, bearing rvituess to you how the love of unere huming and falcomy was already, in his day, degrading the military classes, and, so far from being al necessury adjunct of the noble disposition of lover on solctier, was, even to contempt, showing itself separate from botl.

"Le rie home, cassador,

M'enneion, e'l hruacaclor.

Parlan de rolarla, danstor, Ne jamais d'amas, ni damor." 
The rich man, the chaser,

Tires me to death; and the adorer of bnzzards.

They talk of covey and hawk,

And never of arms, nor of love.

"Cassador," of course, afterwards becomes "chasseur," and "anstor" "rantour." But after you have read this, and familiarized your ear with the old word, how differently Milton's phrase will ring to ron,-- "Those who thonght no better of the Liring God than of a buzzard idol,"--and how literal it becomes, when we think of the actnal difference between a member of Parliament in Milton's time, and the Busacador of to-day; -and all this freshness and value in the reading, observe, come of your lieeping the word which great men have nsed for the bird, instead of letting the anatomists blunder out a new one from their Latin dictionaries.

9. There are not so many nameable rarieties, I jnst now said, of robin as of falcon; but this is somewhat inacenrately stated. Those thirteen birds represented a rery large proportion of the entire group of the birds of prey, which in my serenfold classification I recommended ron to call miversally, "hawks." The robin is only one of the far greater multitude of small birds which live almost indiscriminately on grain or insects, and which I reeommended you to call generally "sparrows;" but of the robin itself, there are two important Enropean rarietiesone red-breasted, and the other blue-breasted. 
10. Ton probably, some of you, never heard of the bluc-breast; rery few, certainly, have secu one alive, and, if alive, certainly not wild in Englanel.

Ilere is a picture of it, daintily done, * and your can see the pretty blue shiekl on its breast, perhaps, at this distance. Tain shield, if erer the fair little thing is wretched enongh to set fout on English groumd: I find the last that was scen was shot at Margate so long ago as $15+2$, - and there seems to be no official record of any risit before that, since M[r. Thomas Embledon shot one on Newrastle town moor in 1816. But this rarity of visit to ns is strange; other birds have no such clear objection to being shot, and really seem to come to Enghand expressly for the purpose. And yet this bluc-bird-(one can't say "blue robin"-I think we shall have to call him "blnet," like the cornflower)-stays in Sweden, where it sings so sweetly that it is called "a hmolred tongues"

11. That, then, is the ntmost whi h the lords of land, and masters of science, do for us in their watch 1 pon on feathered suppliants. One kills them, the other writes classifying epitaphs.

The have next to ask what the poets, painter's, and monks have done.

The poets-annong whom I affectionately and reverently class the sweet singers of the mursery, mothers and

* Mr. Gould's, in his "Birds of Great Britain." 
nurses-lhave done much ; rery nearly all that I care for your thinking of. The painters and monks, the one being so greatly under the influence of the other, we may for the present class together; and may almost sum their contributions to ornithology in saying that they have plucked the wings from birds. to niake angels of nucn, and the claws from birds, to make devils of men.

If you were to take amay from religions art these two great helps of its - I must say, on the whole, very feeble-imagination; if you were to take from it, I say, the power of putting wings on shonlders, and claws on fingers and toes, how wonderfully the sphere of its angelic and diabolic characters would be contracted: Reduced only to the sonrces of expression in face or movenents, you might still find in gond early sculpture very sufficient derils: but the lest angels would resolre themselves, I think, into little more than, and not often into so much as, the likeuesses of pretty women, with that grare and (I do not say it ironically) majestic expression which they put on, when, being rery fond of their hnsbands and children, they serionsty think either the one or the other have misbehared themselves.

12. And it is not a little disconraging for me, and may well make you donbtful of my right judgment in this endeavon to lead yon into closer attention to the bird. with its wings and claws still in its own possession ; - it is disconlaging, I say, to observe that the begimning of such more faithful and accurate observation in former art, is 
exactly eoeral with the commencement of its decline. The fererish and mogracoful natural history of Panl, callerl, "of the hirts." I'aolo deghli Lrecelli, prorluced, indeed, no hamenf result on the minds of his contemporraries; they watched in him, with only contemptnons admiration, the fantasy of zoological instinct which filled his house with painted logss, (ats, and birds, becanse he was too poor to fill it with ral ones. Their juclgnent of this morbidly natmolistic art was conchusively expresiced by the sentence of Donatello, when going one morning into the Old Narket, to buy fruit, and finding the animal painter meorering a pictme, which had cost him months of care, (curionsly symbolic in its subject, the inficlelity of St. Thomas, of the investigatory fingering of the natural historian,) "Pant, my friend," said Donatello, "thon ant meorering the pietme just when thon shouldst be shutting it "тр."

13. No harm, therefore, I repeat, but, on the contrary, some wholesome stimulus to the fancy of nen like Luca and Donatello themselves, came of the grotesque and impertinent zoology of Uccello.

But the fatallest institutor of proud molem anatomical and scientitic art, and of all that has polluted the dignity, and darkened the charity, of the greater ages, was Antonio Pollajuolo of Filonence. Antonio (that is to say) the Ponlterer-so named from the trade of his crindfather, and with just so much of his andudfather" s tranle left in his own disposition, that being set ly Lorenzo 
Ghiberti to complete one of the ornamental festoons of the gates of the Florentine Baptistery, there, (says Tasari) " Intonio produced a quail, which may still be seen, and is so beantiful, nay, so perfect, that it wauts nothing but the power of flight."

14. Here, the morbid tendency was as attractive as it was subtle. Chiberti himself fell under the influence of it; allowed the borders of his gates, with their fluttering birds and bossy fruits, to dispute the spectators' farour with the religious subjects they enclosed; and, from that day forward, minuteness and musenlarity were, with eurious harmony of eril, delighted in together; and the lancet and the microscope, in the hands of fools, were supposed to be complete substitutes for imagination in the sonls of wise men: so that eren the best artists are gradually compelled, or beguiled, into compliance with the cmiosity of their day; and Francia, in the city of Pologna, is held to be a "kind of gend, more particularly" (again I quote Tasari) "after he had painted a set of caparisons for the Duke of Urbino, on which he depicted a great forest all on fire, and whence there rushes forth an immense number of every lind of animal, with several hmman figures. This terrific, yet truly beantiful representation, was all the more highly esteemed for the time that har been expended on it in the plumage of the birds, and other minntio in the delineation of the different animals, and in the dirersity of the branches and leares of the rarious trees 
seen therein;" and thenceformarl the catastrople is direct, to the ornithologival musenus which Brenghel painted for gardens of Eden, and to the still life and dead game of Dutclu celebrities.

15. Anrl ret I an goiner to invite ron to-day to examine, down to almost microscopic detail, the aspect of a small bircl, and to invite you to do this, as a most expedient and sure step in your study of the greatest art.

But the difference in onr motice of examination will entirely alter the result. To paint birds that we may show how minutely we can paint, is anomg the most contemptible occupations of art. To paint them, that we may show how beantiful they are, is not indeed one of its ligghest, but quite one of its pleasantest and most useful; it is a slill within the reach of every student of arerage capacity, and whirh, so far as acquired, will assuredly both make their hearts kinder, and their lives happier.

Withont further preamble, I will ask rou to look to-day, more carefully than nsual, at your well-known faromrite, and to think about him with some precision.

16. And first, Where does he come from? I stated that my lectures were to he on English and Greek birds; but we are apt to fancy the robin all our own. How exchusirely, do you suppose, he really belong's to ns? Iin wonld think this was the first point to be settled in any book about him. I have hunted all my books through, 
and can't tell you how much he is our own, or how far he is a traveller.

And, indeed, are not all our ideas obscure abont migration itself? Ton are broadly told that a bird travels, and how wonderful it is that it finds its way; but you are scarcely ever told, or led to think, what it really travels for-whether for food, for warmth, or for seclusion-and how the travelling is connecterl with its fixed home. Pirds have not their town and country houses,-their villas in Italy, and shooting boxes in Scotland. The comntry in which they build their nests is their proper home, -the conntry, that is to say, in which they pass the spring and smmmer. Then they go sonth in the winter, for food and warnth; but in what lines, and by what stages? The general definition of a migrant in this hemisphere is a bird that goes north to build its nest, and south for the winter; but, then, the one essential point to know about it is the breadth and latitude of the zone it properly inhal,its, - that is to say, in which it builds its nest; next, its habit of life, and extent and line of sonthing in the winter ; and, finally, its manner of travelling.

17. Now, here is this entirely familiar bird, the robin. Quite the first thing that strikes me abont it, looking at it as a painter, is the small effect it seems to have had on the minds of the sonthern nations. I trace nothing of it definitely, either in the art or literature of Greece or Italy. I find. even, no definite name for it; you don't know if Lesbia's "passer" had a red hreast, or a blue, or" 
a brown. And yet Mr. Gonlel says it is abmulant in all parts of Finnope, in all the islancls of the Merliteriancans. and in Madeira and the Azores. And then he sals:(now motice the puzzle of this), - - In man! latts of the Continent it is a migrant, and. contrary to what ohtains with ns, is there treated as a vagrant, for there is scarcely a comtry across the water in which it is not shot down and eaten."

"In many parts of the Continent it is a migrant." In what parts-how far-in what mamer?

19. In none of the old natural history books can I find any accomt of the rolin as a traveller, but there is. for once, some sufticient reason for their reticence. He has a curions fancy in his manner of travelling. Of all hirds, you would think he was likely to do it in the cheerfullest way, and he does it in the sadrlest. Do rom chance to hare read, in the Life of ( harles I)ickens. how fomd he was of taking long walks in the night and alone? The robin, en rorage, is the Charles Dickens of birks. JIe always travels in the night, and alone; rests, in the dar. whererer day chances to find lim; sings a little. and pretends he hasn't been anywhere. He groes as far. in the winter, as the north-west of Africa; and in Lombardy, arrives from the sonth carly in March: but does not stay long: going on into the Alps, where he prefers wooded and wild districts. So, at least, says my Lombarl informant.

I do not find him named in the list of Cretan birds; 
but eren if often seen, his dim red breast was little likely to make much impression on the Greeks, who knew the fiamingo, and had made it, under the name of Phœnix or Phouicopterns, the centre of their myths of scarlet birds. They broadly embraced the general aspect of the smaller and more obscure species, mider the term $\xi_{0} \theta 0$, which, as I mderstand their nse of it, exactly implies the indescribable silky brown, the groundwork of all other colour in so many small birds, which is indistinct among green leares, and absolntely. identifies itself with dead olles, or with mossy stems.

19. I think I show it you more accurately in the rubin's back than I could in any other bird; its mode of transition into more brilliant colour is, in him. elementarily simple; and althongh there is nothing. or rather becanse there is nothing. in his plnmage, of interest like that of tropical birds, or eren of our orn game-birds, I think it will be desirable for yon to learn first from the breast of the robin what a feather is. Once knowing that. thoronghly, we can further learn from the swallow what a wing is; from the chongh what a beak is; and from the falcon what a claw is.

I must take are, howerer, in neither of these last two particulars to do injustice to onr little English friend here; and before we come to his feathers, must ask you to look at his bill and his feet.

20. I 1 w not think it is distinetly enough felt by us that the beak of a bird is not only its mouth, but its hand, or 
rather its two lands. For, as its arms and liands are turned into wings, all it has to depend mpen, in economical and practical life, is its beak. The beak, there- fore, is at once its sword, its carpenter's tool-box, and its dressing-case; partly also its musical instrument; all this besides its function of seizing and preparing the food. in which functions alone it has to be a trap, carring-knife, and teeth, all in one.

21. It is this need of the beak's being a mechanical tool which rhiefly regulates the form of a bird's face, as opposed to a fomr-footed animal's. If the question of food were the only one, we night wonder why there were not more four-footed creatures living on seeds than there are; or why those that do-field-mice and the like-hare not beaks instead of teeth. Bnt the fact is that a bird's leak is by no means a perfect eating or food-seizing iustrument. A squirrel is far more dexterous with a nut than a cockatoo: and a dog manages a bone incomparably better than an eagle. But the beak has to do so much more! Pruning feathers, building nests, and the incessant discipline in military arts, are all to be thought of, as much as feeding.

Soldiership, especially, is a much more imperions necessity among birds than quadrupeds. Neither lions nor wolres habitually use claws or teeth in contest with their own species; but birds, for their partners, their nests, their hunting-grounds, and their personal dignity, are nearly always in contention; their conrage is muequalled 
by that of any other race of animals capable of comprehending danger; and their pertinacity and endnrance have, in all ages, made them an example to the brave, and an ammenent to the base, among mankind.

22. Nerertheless, since as sword, as trowel, or as pocketcomb, the beak of the bird has to be pointed, the collection of seeds may be conveniently entrusted to this otherwise penetrative instrument, and such food as can only be obtained by probing crevices. splitting open fiswese, or lieatly and minntely picking things up, is allotter, pre-eminently, to the bird species.

The fool of the robin, as yon know, is rery miscellaneons. Limmens says of the Swedish one, that it is "delectatus enomyni baccis," - "delighted with dogwood berries,"-the dogrrood growing almutantly in Sweden. as once in Forfarshire, where it grew, thongh only a bush nsually in the sonth, with trunks a foot or eighteen inches in diameter, and the tree thirty feet high. But the Swedish robin's taste for its herries is to be noted by you, because, first, the dogwool berry is commonly said to he so bitter that it is not eaten by birds (London, "Arboretum," ii., 497, 1.); and, secondly, because it is a pretty coincidence that this most familiar of household birds shonld feed fondly from the tree which gives the housewife her spindle,-the proper name of the dogwood in Euglish, French, and German being alike "Spindle-tree." It feeds, howerer, with us, eertainly, most on worms and insects. I am not sure how far the following account of 
its mode of dressing its dimmers may be depender on: I take it from an old book on Natmal Histery, lont find it, more or less, eonfirmed by others: " It takes a worm lyy one extremity in its beak, and beats it on the gromnd till the inner part comes away. Then seizing it in a sinilar manner l,y the other end, it entirely cleanses the onter part, which alone it cats."

One's first impression is that this must he a singularly mpleasant operation for the worm, howerer fastidionsly delicate and exemplary in the robin. Thut I suppose the real meaning is, that as a worm lires l,y passing earth through its body, the robin merely compels it to quit this -not ill-gotten, indeed, but now quite muecessarywealtl. Wre human creatures, who have lived the lives of rorns, collecting dust, are served by Death in exactly the same manner.

23. Iou will find that the rolnin's beak, then, is a very prettily representative one of general bird puwer. Is a meapon, it is very formidable indeed: he can kill an anversary of his own kind with one blow of it in the throat; and is so pugnacions, "valde pugnax," says Limmens, " nt non ma arbor duos capiat erithacos,"- "no single tree can hold two cock-robins;" and for precision of seizme, the little flat look at the end of the upper mandible is one of the most delicately formed prints of forceps which you can find among the grain eaters. But I pass to one of his more special perfections.

24. Te is very notable in the exquisite silence and pre- 
cision of his morements, as opposed to lirds who either creak in flying, or waddle in walking. "Always quiet," says Gould, 'for' the silkiness, of his plumage renders his morements noiseless, and the rustling of his wings is never heard, any more than his tread on earth, over whick he bounds with amazing sprightliness." Tou know hor much importance I have always given, among the fin. arts, to good dancing. If you think of it, you will find one of the rubin's very chief ingratiatory faculties is his dainty and delicate morement, - his footing it featly here and there. Whaterer prettiness there may be in his red breast, at his brightest he can always be outshone by a brickbat. Tut if he is rationally proud of anything about him, I should think a robin must be prond of his legs. Thundreds of birds have longer and more inposing onesbut for real neatness, finish, and precision of action, commend me to lis fine little ankles, and fine little feet; this long stilted process, as you know, corresponding to our ankle-bone. Commend me, I say, to the robin for use of his ankles-he is, of all birds, the pre-eminent and characteristic ILoper; none other so light, so pert, or so swift.

25. We must not, howerer, give too much credit to his legs in this matter. A robin's hop is half a flight; he hops, very essentially, with wings and tail, as well as with his feet, and the exquisitely rapid opening and quivering of the tail-feathers certainly give half the force to his leap. It is in this action that he is put among the mota- 
cillae, or wagtails; lut the ornithologists have no real bnsiness to put him among them. T'he swing of the long tail-feathers in the true wagtail is entirely consequent on its motion, not impulsive of it-the tremulons shake is "ftei alighting. Jint the robin leaps with wing, tail, and foot, all in time, and all helping each other. Lcaps, I say ; and you check at the word; and onght to check: you look at a bird hopping, and the motion is so unch a matter of course, you never think low it is done. But do yon think you would find it easy to hop like a robin if you had two-all but wooden-legs, like this?

26. I have looked wholly in vain through all my books on birds, to find some acconnt of the muscles it nses in hopjuing, and of the part of the toes with which the spring is giren. I must leave you to find ont that for yourselves; it is a little bit of anatony which I think it highly desirable for yon to know, but which it is not my business to teach yon. Only observe. this is the point to be made out. You leap yourselves, with the toe and ball of the foot; but, in that power of leaping, yon lose the faculty of grasp; on the contrary, with your hands, yon grasp as a bird with its feet. lint your caunot hop on your hands. A cat, a leopard, and a monker, leap or grasp with equal ease; but the action of their paws in leaping is, I inagine, from the fleshy ball of the foot: while in the bird, characteristically $\gamma \alpha \mu \psi \hat{\omega} \nu v \xi$, this fleshy ball is rednced to a boss or series of hosses, and the mails are elongated into sickles or horns; nor does the springing fower seem 
to depend on the derelopment of the bosses. They are far more dereloped in an eagle than a robin; but yon kwow how unpardonably and preposterously awkward an eagle is when he hops. When they are most of all developed, the lircl walks, runs, and digs well, but leaps badly.

27. I hare no time to speak of the rarions forms of the ankle itself, or of the scales of armonr, more aptarent than real, by which the foot and ankle are protected. The nze of this lecture is not either to describe or to exhibit these varieties to you, but so to awaken ynur attention to the real points of character, that, when yon hare a bird's foot to draw, you may do so with intelligence and 1'leasnre, knowing whether you want to express force, grasp, or firm ground pressure, or dexterity and tact in motion. And as the actions of the foot and the hand in mum are made by every great painter perfectly expressice of the character of mind, so the expressions of rapacity, cruelty, or force of seizure, in the harps, the gryphon, and the hooked and clawed exil spirits of early religions art, (an only be felt by extreme attention to the original form.

25. And now I retum to onr main question, for the robin's breast to answer, "Thlut is a feather": Ton know something about it alrealy; that it is composed of a quill, with its lateral filanents, teminating senerally, more or less, in a point: that these extremities of the "puills, lying over each other like the tiles of a honse, allow the wind and rain to pass over them with the least losille resistance, and form a protertion alike from the 
heat and the cold; which, in structure mnch resembling the scale-armonr assmmerl by man for very different objerts, is, in fact, intermediate, exactly, between the fur of beasts and the scales of fishes; having the minute division of the one, and the amonr-like symmetry and succession of the other:

29. Not merely symmetry, observe, but extreme flatness. Feather's are smoothed down, as a fiekl of coln by wind with rain; only the swathes laid in beantifnl order. They are fur, so structurally placed as to imply, and submit to, the perpetnally swift forwarel motion. In fact, I have no doubt the Darwinian theory on the subject is that the feather's of birds once stuck up all erect, like the bristles of a brush, and have only heen blown flat by contimnal flying.

Nay, we might eren suffiviently represent the greneral manner of conclusion in the Darwinian system by the statement that if you fasten a hair-bruslı to a mill-whecl, with the handle forward, so as to develop itself into a neck by moving always in the same direction, and within contimal hearing of a steam-whistle, after a certain 1 mmber of revolutions the hair-brush will fall in Inve with the whistle; they will marry, lay an egg, and the produce will be a nightingale.

30. Whether, however, a hog's hristle can turn into a feather or not, it is vital that you should know the present difference between them.

The scientific people will tell you that a feather is conn- 
posed of three parts-the down, the laminæ, and the shaft.

But the common-sense method of stating the matter is that a feather is composed of two parts, a shaft with lateral filaments. For the greater part of the shaft's length, these filaments are strong and nearly straight, forming, by their attachment, a finely warped sail, like that of a windmill. But towards the root of the feather they suddenly becone weak, and confusedly flexible, and form the close down which immediately protects the bird's body.

To show you the typical arrangement of these parts, I choose, as I have said, the robin; because, both in his power of flying, and in his colomr, he is a moderate and balanced

FIG. 1.

(Twice the size of reality.)

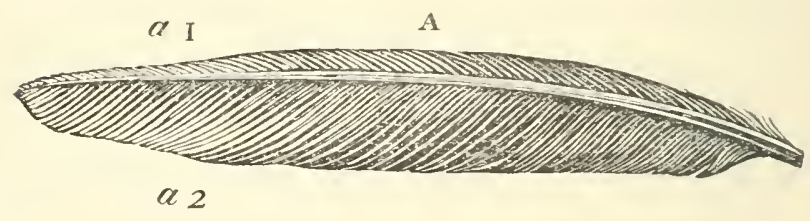

B

bird; - not turned into nothing but wings, like a swallow, or nothing but neck and tail, like a peacock. And first 
for his thing power. There is me of the long feathers of robin's wing, and here (Fig. 1) the analysis of its form.

31. First, in pure ontline ( 1 ), seen from abore, it is very nearly a long oval, but with this peculiarity, that it has, as it were, projecting shoulders at " 1 and $\approx 2$. I merely desire yon to observe this, in passing, becanse one nsmally thinks of the contour as sweeping nubroken from the root to the point. I have not time to-day to enter on any discussion of the reason for it, which will appear when we examine the placing of the wing-feathers for their stroke.

Now, I hope yon are getting accustomed to the general method in which I give you the analysis of all formsleaf, or feather, or shell, or limb. First, the plan; then the profile; then the cross-seetion.

I take next, the profile of my feather (в, Fig. 1), and find that it is twisted as the sail of a windmill is, but more distinctly, so that yon can always see the upper surface of the feather at its root, and the monder at its end. Every primary wing-feather, in the fine flyers, is thus twisted; and is best described as a sail striking with the power of a scymitar, but with the Hat instead of the edge.

32. Further, yon remember that on the edges of the broad side of feather's you find always a series of mudulations, irregnlarly sequent, and lapping orer each other like waves on sand. You might at first inagine that this 
appearance was owing to a slight ruflling or disorder of the filanents; but it is entirely normal, and, I doubt not, so constructed, in order to ensure a redundance of material in the plume, so that no accident or pressure from wind nuy leave a gap anywhere. How this redundance is oltained yon will see in a noment by bending any feather the wrong way. Bend, for instance, this phme, l,

FIG. 2.

$\Lambda$
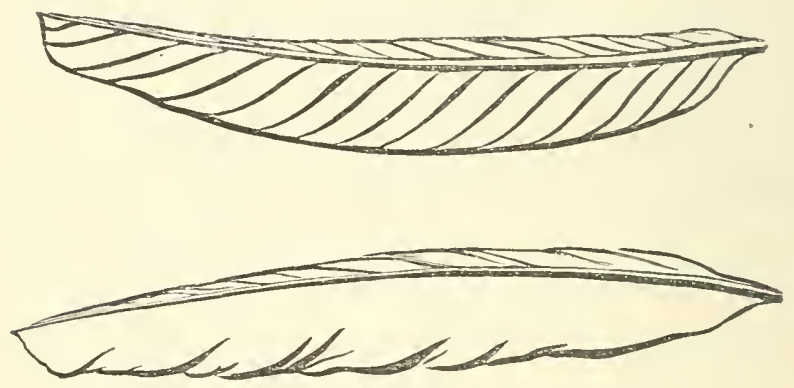

13

Fig. 2, into the reversed curve, 1, Fig. 2; then all the filaments of the plume become perfectly even, and there are no waves at the edge. But let the plume return into its proper form, s, and the tissue being now contracted into a smaller space, the edge waves are formed in it instantly.

Ilitherto, I have been speaking only of the filaments arranged for the strength and contimnity of the energetic plume; they are entirely different when they are set 
together for decoration instead of foree. After the feather of the robin's wing, lot us examine one firm his lineast.

33. I said, just now, he might be at once ontshone hy a brickluat. Interl, the day before yesterday, slecping at Lichficld, and seeing, the first thing when I woke in the morning, (for l never put down the blinds of my bedrom windows, the not mucommon sight in an English comntry town of an entire house-front of very neat, and very flat, and rery red luicks, with very exactly squared square windows in it; and not feeling myself in anywise gratified or inproved ly the spectacle, I was thinking how in this, as iu all other grood, the too much clestroyed all. The breadth of a robin's loreast in brick-red is delicions, but a whole homse-front of hrick-red as vivid, is alaming. And get one camnot generalize even that trite moral with any safety-for infinite breadth of green is delightful, how. ever green; and of sea or sky, howerer blue.

Tou must note, howerer, that the rolnin's "hisun is greatly helped by the pretty space of grey plumare which separates the red from the lorwn back, and sets it off to its lest adrantage. There is no werelt brilliancy in it, eren so relieved; only the finish of it is exquisite.

34. If you separate a single feather, you will fincl it more like a transparent hollow shell than a feather (so delicately romuded the surface of it), -grey at the root, where the down is,-tinged, and only tinged, with red at the part that overlaps and is visible; so that, when thee 
or four more feathers have orerlapped it again, all together, with their joined red, are just enough to give the colour determined upon, each of them contributing a tinge. There are abont thirty of these glowing filaments on each side, (the whole being no larger across than a well-grown currant,) and each of these is itself another exquisite feather, with central quill and lateral webs, whose filaments are not to be counted.

The extremity of these breast plumes parts slightly into two, as you see in the peacock's, and many other such decorative ones. The transition from the entirely leaf-like shape of the active phume, with its oblique point, to the more or less symmetrical dualism of the decorative plume, corresponds with the change from the pointed green leaf to the dnal, or heart-shaped, petal of many flowers. I shall return to this part of our subject, having giren you, I believe, enongh of detail for the present.

35. I have said nothing to-day of the mythology of the bird, thongh I told you that would always be, for us, the most important part of its matnral history. But I am (b)iged, sometimes, to take what we immediately want, rather than what, ultimately, we shall need chiefly. In the second place, you probably, must of you, know more of the mythology of the robin than I do, for the stories about it are all northern, and I know scareely any myths but the Italian and Greek. Yon will find muder the name "Robin," in Miss Yonge's exhanstive and admirable "IIistory of Christian Nimes," the rarions titles of hon- 
onr and endearment comnected with him, and with the general idea of rechess, - from the bishop called "Bright Red Fame," who fomded the first great Christian church on the Rhine, (I an afraid of your thinking I mean a pun, in connection with lobins, if I tell you the locality of it,) down through the Hoods, and Roys, and Grays, to Robin Goodfellow, and Spenser's "IIobbinol," and on" modern "I Iob,"-juining on to the "gol)lin," which comes from the old Greek Kóßàos. But I cammot let yon go withont asking you to compre the English and French feeling about small birds, in Chancer's time, with our own on the same sulject. I say English and French, becanse the original French of the Riomance of the Rose shows more affection for birds than eren Chancer's translation, passionate as he is, ahways, in luve for any one of his little winged brothers or sister's. Look, howerer, either in the French or English, at the description of the coming of the God of Love, leading his carol-dance, in the garden of the Rose.

His dress is embroidered with fignres of flowers and of beasts; but about him fly the living birds. 'The French is :
Il etoit tout courert d'oisiaulx
De rossignols et de papegaux
De calendre, et de mesangel.
Il semblait que ce fut une angle
Qui fuz tout droit vennz du ciel

36. There are sereral points of philology in this transitional French, and in Chancer's translation, which it is $2 *$ 
well worth your patience to observe. The monkish Latin "angelus," you see, is passing throngh the rery unpoetical form "angle," into "ange;" but, in order to get a rhyme with it in that angular form, the French troubadon expands the bird's name, "mesange," quite arbitrarily, into "mesangel." Then Chancer, not liking the "mes" at the beginning of the rord, changes that muscrupulonsly into "arch;" and gathers in, though too shortly, a lorely bit from another place abont the nightingales flying so close round Love's head that they strike some of the leares off his crown of roses; so that the English runs thus:

\footnotetext{
But nightingales, a full great rout That flien over his head about, The leaves felden as they flien And he was all with birds wrien, With popinjay, with nightingale,

With chelauudre, and with wodewale, With finch, with lark, and with archangel.

Ile seemed as he were an angell, That down were comen from Hearen clear.
}

Now, when I first rearl this bit of Chancer, withont referring to the original, I was greatly delighted to find that there was a bir! in his time called an archangel, and set to work, with brightly hopeful industry, to find out what it was. I was a little discomfited by finding that in old botany the word only meant "dead-nettle," but was still sanguine about my hird, till I fomd the French form descend, as yon have seen, into a mesangel, and finally into mesange, which is a provincialism from $\mu \in \iota \nu$ 
and means, the smallest of lirds-or, specially here,-a titmonse. I have selfom had a less expected or mole ignominious fall from the conds.

37. The other hirels, maned here and in the previons description of the ramden, are introduced, as fill as I can judge, nearly at random, and with mo preeision of inatginatiom like that of Aristophames; but with a sweet ehilhlish delight in crowding as many birds as possible into the smallest space. The popinjay is always prominent; and I want some of you to help) me (for. I have not time at present for the (hase) in hunting the parrot down on his first appearance in Europe. Just at this particular time he contested favotir even with the falcon; and I think it a piece of good fortme that I chanced to draw for you, thinking only of its brilliant colour, the popinjay, which (arpaccio allows to be present on the grave occasion of St. Georges baptizing the princess and her father.

3. And, indeed, as soom as the Christian pots hegrin to speak of the singing of the binds, they show thenselves in quite a different mood from any that ever oreurs to a Greek. Aristophanes, with infinitely more skill, describes, and partly initates, the singring of the nightingale; but simply as leantiful somnd. It "fills the thickets with honey;" and if in the often-quoted-just becanse it is not characteristic of Greek literature-patisane of the Colonens, a deeper sentiment is shown, that fereling is dependent on association of the hird-roices with deeply pathetic circumstances. lint this troubaclon. 
finds his heart in heaven by the power of the singing only :-

\section{Trop parfoisaient beau servise \\ Ciz oiselles que je vous devise. \\ Il chantaient un chant ytel \\ Com fussent angle esperitel.}

We want a moment more of word-chasing to enjoy this. "Oisean," as you know, connes from "avis;" but it had at this time got "oisel" for its singular number, of which the terminating "sel" confused itself with the "selle," from "ancilla" in domisella and demoiselle; and the feminine form "oiselle" thus snatehed for itself some of the delightfulness belonging to the title of a young lady. Then note that "esperitel" does not here mean nerely spiritual, (becanse all angels are spiritual, but an "angle esperitel" is an angel of the air. So that, in English, we conld only express the meaning in some such fashion as this :-

They perfected all their service of Love, These maiden birds that I tell you of. They sang sueh a song, so finished-fair, As if they were angels, horn of the air.

39. Such were the fancies, then, and the scenes, in which Englishmen took delight in Chancer's time. England was then a simple country; we boasted, for the best kind of riches, onr birds and trees, and onr wives and children. We have now grown to be a rich one; and onr first pleasure is in shooting onr birds; but it has become too expensive for us to keep our trees. Lord Derly, 
whose crest is the eagle and child-ron will find the northern name for it, the hird and bantling, manle alassiall by seott--is the first to propose that work-birds should lave no more nests. TVe nust cent down all om* trees, he salys, that we may effectively use the steamplongh; and the effect of the steam-plongh, I find hy a recent article in the " Cornhill Magazine," is that an English labourer must not any more have a nest, nor lonutlings, neither; but may only expect to get on prosperously in life, if he be perfectly skilful, solber, and honest, and dispenses, at least until he is forty-five, with the "luxwry of marriage."

40. Gentlemen, you may perlaps have heard me blamed for making no effort here to teach in the artizans' schools. But I can only say that, since the future life of the English labourer or artizan (sumning the benefits to him of recent philosopliy and economy) is to be passed in a country withont angels and withont birds, without prayers and without songs, withont trees and withont flowers, in a state of exemplary sobriety, and (extending the Catholic celihacy of the clergy into celibacy of the laity) in a state of dispensation with the luxury of marriage, I do not believe he will derive either profit or entertainment from lectures on the Fine drts. 


\section{LECTLRE II.}

TIIE SWALLOW.

41. Ww are to-day to take note of the form of a creature which gives us a singular example of the unity of what artists call beanty, with the fineness of mechanical structure, often mistaken for it. Tou cannot but have noticed how little, during the years of my past professorship, I have introduced any questions as to the nature of beauty. I aroided them, partly because they are treated of at length in my books; and partly becanse they are, in the last degree, mpractical. The are born to like or dislike certain aspects of things; nor could I, by any argmments, alter the defined tastes which you receired at your birth, and which the surromding circmmstances of life have enforced, withont any possibility of your voluntary resistance to them. And the result of those surrounding circumstances, to-day, is that most English youths wonk have more pleasure in looking at a locomotive than at a swallow; and that many English plilosphers would suppose the pleasnre so receired to the throngh a new sense of beanty. But the meaning of the word "beanty" in the finc arts, and in classical literature, is properly restricted to those very qualities in which 
the locomotion of a swallow differs from that of an engine.

42. Not only from that of an engine; but also from that of animals in whose memhers the mechanism is so complex as to give then a resemblance to engines. The dart of the common louse-ty, for instance, in full strength, is a more wonderful movement than that of a swallow. The nechanism of it is not only more minnte, but the swiftness of the action so much greater, that the vibration of the wing is invisible. But though a scloonboy might prefer the locomotive to the swallow, he wonld not carry his admiration of finely mechanical velocity into muquafied sympathy with the workmanship of the God of Ekron; and would generally smppose that flies were made only to be food for the more graceful $\mathrm{H}_{\mathrm{y}}$ catcher,-whose tiner grace yon will discover, "pon reflection, to be owing to the rery moleration and simplicity of its structure, and to the subrluing of that infinitude of joints, claws, tissues, veins, and fibres which inconceivably vilurate in the microscopic * creature's motion, to a cuite intelligible and simple balance of rounded borly upon edged plume, maintained not without visible, and sometimes fatigued, exertion, and raising the lower creature into fellowship with the volition and the virtue of liumanity.

* I call it so because the members and action of it cannot be seen with the unaided eje. 
43. With the virtue, I say, in an exceedingly qualified sense; meaning rather the strongth and art displayed in orerconning difliculties, than any distinct morality of disposition. The bird has kindly and honely qualities; bnt its principal "virtne," for $u s$, is its being an incarnate voracity, and that it mores as a consmming and cleansing power. Ion sometimes hear it said of a hmmane person that he would not kill a fly: from 700 to 1000 flies a day are a moderate allowance for a baby swallow.

44. Perhaps, as I say this, it may occur to some of yon to think, for the first time, of the reason of the bird's name. For it is rery interesting, as a piece of language study, to consider the different power on omr minds,-nay the different sweetness to the ear,-which, from association, these same two syllables receive, when we read them as a nomn, or as a rerb. Also, the word is a curions instance of the traps which are continually open for rash efynologists. At first, nothing ronld appear more natural than that the name shonld have been given to the bird from its reckless function of devonring. But if you look to your Johnson, you will find, to your better satisfaction, that the name means "bird of porticos," or porches, from the Crothic "swale;" "subdivale,"--so that it goes back in thought as far as Virgil's, " Et nunc. porticibus vacuis, nunc humida circum, stagna sonat." Notice, in passing, how a simile of Tirgil's. or any other great master's, will probably tell in two or more ways at once. Juturna is compared to the swallow, not merely as 
winding and tuming swiftly in her chariot, but as heing a water-nymple by birth,-... Stagnis quate, Huminilusprue sonoris, praesidet." How many different creatmes in we the swallow is by birth, as a Virgilian simile is many thomghts in one, it would take many more lectures than one to show you clearly: but I will indicate them with such rough sketclu as is possible.

t5. It belongs, as most of yom know, to a fanily of birds alled Fissi-rostres, or, literally, split-buaks. Split heads wonld be a better term, for it is the enormons width of month and power of ganping which the epithet is meant to express. A dull sermon, for instance, makes half the congregation " fissi-rostres." The bird, however, is most rigilant when its month is widest, for it opens as a net to catch whatever comes in its way,-hence the French, giving the whole family the more literal name, "Gobble-fly" -Gobe-mouche, extend the ter"n to the open-mouthed and too aceeptant appearance of a simpleton.

46. Partly in order to provide for this width of month, but more for the adrantage in flight, the head of the swallow is romded into a bullet shape, and sumk down on the shoulders, with no neck whatever between, so as to give nearly the aspect of a conical rifle bullet to the entire front of the body; and, indeed, the bird moves more like a bullet than an arrow-depundent on a certain impetns of weight rather than on sharp penetration of the air. I say dependent on, but I have not yet been able to trace 
distinct relation between the shapes of birds and their powers of thight. I suppose the form of the body is first determined by the general habits and fook, and that nature can make any form she chonses volatile; only one point I think is always notal) le, that a complete master of the art of thight must be short-necked, so that he turns altogether, if he turns at all. Tou don't expect a swallow to look romd a corner before he gues romel it; he must take his chance. The main point is, that he may be able to stop himself, and turn, in a monent.

47. The stopping, on any terms, is difficult enough to understand ; nor less so, the original gaining of the pace. We always think of flight as if the main diffienlty of it were only in keeping up in the air;-but the bnoyancy is conceivable enongh, the far more wonderful matter is the getting along. Fou find it hard work to row yourself at anything like speed, though your impulse-stroke is given in a heary element, and your return-stroke in a light one. But both in birds and fishes, the impelling stroke and its return are in the same element; and if, for the lird, that modim yields easily to its impulse, it secedes as easily from the blow that gives it. And if you think what an effort you make to leap six feet, with the earth for a fulcrum, the dart either of a tront or a swallow, with no fukcrum but the water and air ther penetrate, will seem to yon, I think, greatly marvellons. Tet of the mocke in which it is accomplished you will as yet find 110 1n1disputed accomnt in any book on natmal history, and 
scarcely, as far as I know, lefinite notice even of the rate of flight. What do rom suppose it is? We are alpt to think of the migration of a swallow, as we should ompselves of a serions jonrney. How long, do you think, it would take him, if he flew minterruptedly, to get from here to Ifrica?

48. Michelet gives the rate of his flight (at full speed, of comrse.) als eighty leagnes an homr. I tind no nore somul authority; lut do not dombt his approximate acenracy ; * still how enrions and how provoking it is that neither White of Selborne, Jewick, Iarrell, nor Gould, says a word about this, one shonld have thought the most interesting, power of the bird. $\dagger$

Taking Michelet's estimate-eighty French leagues, ronghly two hundred and fifty miles, an honr-we have a thousand miles in four hours. That is to say, learing Devonshire after an early breakfast, he could be in Ifrica to lunch.

49. Ile conld, I say, if his flight were constant; lut thongh there is much inconsistency in the accomnts, the sum of testimony seems definite that the swallow is anong the most fatiguable of birds. "When the weather is

* I wrote this some time ago, and the exdeavour I lave since made to verify statements on points of matural history which I had taken on trust have given me reason to doubt everybody's accuracy. The ordinary flight of the swallow does not, assuredly, even in the dashos, reach anything like this speed.

f Incidentally suggestive sentences occur in the history of Selborne, but its author never comes to the point, in this case. 
hazy;" (I quote Yarrell) "they will alight on fishingboats a league or two from land, so tired that when any one tries to catch them, they can scarcely fly from one end of the boat to the other."

I have no time to read to you the interesting evidence on this point given ly Sarrell, but only that of the brother of White of Selhorne, at Gilualtar. "My brother lats always found," he himself writes, "that some of his birds, and particularly the swallow kind, are very sparing of their pains in urosing the Mediterranean; for when arrived at Gibraltar, they do not 'set forth their airy cararan, high over seals,' but scont and hurry along in little detached parties of six or seren in a company ; and sweeping low, just orer the surfice of the land and water, direct their comrse to the opposite continent at the narrowest passage they (an find."

50. You will olserve, howerer, that it remains an open question whether this fear of the sea may not be, in the swallow, like ours of the desert. The commissariat department is a serions one for birds that eat a thousand flies a day when just ont of the egrg; and it is possible that the weariness of swalluws at sea may depend much more on fasting than flying. (aptain (or Admiral?) Sir Charles Wager says that "one spring-time, as he eame into somdings in the English Chamnel, a great flock of swallows cane and settled on all his rigging; every rope was covered; they hung on one another like a swarm of bees; even the decks were filled with them. They seemed 
almost famished and spent, and were only feathers and bone; bnt, being recruited with a night's lest, touk their flight in the morning."

51. Now I retain you on this point somewhat, becanse it is intimately comnected with a more important one. I told yom we should learn from the swallow what a wing was. Few other birds approach him in the beanty of it, or aplyent power. And yet, after all this care taken about it, he gets tired; and instead of flying, as we shomld do in his place, all over the world, and tasting the flarour of the midges in every marsh which the infinitude of human folly has left to breed gnats instead of growing corm, - he is of all birds, characteristically, except when he absolutely can't help it, the stayer at home; and contentedly lodges himself and his family in an old chimney, when he might be tlying all orer the workl.

At least ron wonld think, if he built in an English chimmey this year, he wonld build in a French one next. But no. Michelet prettily says of him, "lle is the bird of return." If you will only treat him kindly, year after year, he comes back to the same niche, and to the same hearth, for his nest.

To the same niche; and bnilds himself an opaque walled honse witlin that. Think of this a little, as if you heard of it for the first time.

52. Suppose you had nerel seen a swallow; but that its general habit of life had heen deseribed to you, and you had been asked, how you thonght such a bird would build 
its nest. A creature, observe, whose life is to be passed in the air; whose beak and throat are shaped with the fineness of a net for the catching of gnats; and whose feet, in the most perfect of the species, are so feeble that it is called the Footless Swallow, and camnot stand a moment on the ground with comfort. Of all land birds, the one that has least to do with the earth; of all, the least disposed, and the least able, to stop to pick anything up. What will it build with? Gossamer, we shonld say,-thistledown,-anything it can catch floating. like tlies.

But it builds with stiff clay.

53. And observe its chosen place for building also. Ton would think, by its play in the air, that not only of all birds, but of all creatures, it most delighted in space and freedom. Tou would fancy its notion of the place for a nest wonld be the openest field it conld find; that anything like continement wonld be an agony to it ; that it rould ahmost expire of horror at the sight of a black hole.

And its farourite home is domm a chimmey.

54 . Tot for your hearth's sake, nor for your company's. Do not think it. The bird will lore rou if you treat it kindly; is as frank and friendly as bird can be; bnt it does not, more than others, seek your society. It comes to gom house because in no wild wood. nor rongh rock, (an it find a cavity close enongh to please it. It comes for the blessedness of imprisonment, and the solemnity 
of an nubroken and constant shadow, in the tower, or under the eares.

Do you suppose that this is part of its necessiry ecounny, and that a swa!low conld not catch thies muless it lived in a hole?

Not so. This instinct is part of its brotherhoor with another race of creatures. It is given to complete a mesh in the reticulation of the orders of life.

5.). I have already given you several reasons for my wish that you should retain, in classifying birds, the now rejected order of Picae. I an going to read fon a passage from Humboldt, which shows you what difficulties one may get into for want of it.

You will find in the second volume of his personal narrative, an account of the cave of Caripe in New Andalusia, which is inhabited by entirely nocturnal birds, laving the gaping muths of the grat-suclier and the swallow, and yet feeding on fruit.

Unless, which Mr. Hnmboldt does not tell us, they sit under the trees outside, in the night time, and holl their months open, for the berries to drop into, there is not the smallest occasion for their having wide months, like swallows. Still less is there any need, since they are fruit eater's, for their living in a carem 1,500 feet ont of daylight. They have only, in consequence, the troul)le of arrying in the seeds to feerl their young. and the flom of the care is thus corered, ly the seeds they let fall, with a growth of unfortunate pale plants, which have never seen 
day. Nay, they are not eren content with the darkness of their are; but build their nests in the funnels witl which the roof of the grotto is pierced like a siere; live actually in the chimmer. not of a lonse, but of an Egyptian sepulchre! The colom of this bird, of so remarkable taste in lodging, IInmboldt tells us, is "of dark bluish-grey, mixed with strealis and specks of black. Large white spots, which have the form of a heart, and which are bordered with black, mark the head, the wings, and the tail. The spread of the wings, which are compused of serenteen or eighteen quill feather's, is three feet and a half. Suppressing, with Mr. Cnvier, the order of Picae, we must refer this extrandinary bird to the syurrowe."

56 . The can only suppose that it must be, to our popular sparrows, what the swallow of the cimnamon comntry is to onr subordinate swallow. Do you recollect the cinnamon swallows of Ilerodotus. who build their mod nests in the faces of the cliffs where Diomusos was brought up, and where nobodr cam get near then; and how the cinnamon merchants fetch them joints of meat, which the madrised birds, Hying up to their nests with, instead of cinnamon,-nest and all come down together,--the original of Sindbad's ralley-of-diamond story?

57. Well. Hnmblelt is redneed, br necessities of recent classification, to call a bird three feet and a half across tho wings, a sparror. I bave no right to langh at him, for I am just going. myelf, to call the cheerfullest and bright- 
est of birds of the air, an owl. All these arclitectural and sepulchal habits, these Egyptian nummers of the sand-mantin, digrging caves in the sand, and bordertronere"s habits of the chimmey swallow, living in romel towers instead of open air, belong to them as connected with the tribe of the firleoms throngh the owls! and not only so, but with the mammalia throngh the bats! $A$ swallow is an enancipated owl, and a glorified bat; but it never forgets its fellowship with night.

5s. Its uncient fellowship, I had nearly written; so natural is it to think of these similarly-minded creatures, when the feelings that both show are evidently nseless to one of them, as if the inferior lad changed into the higher. The doctrine of developunent scems at first to explain all so pleasantly, that the scream of eonsent with which it las been accepted $1, \mathrm{x}$ men of science, and the shriller vociferation of the public's gregarions applause, scarely permit you the power of antagonint reflection. I must justify to-day, in grarel tone than usual, the terms in which I have hitherto spoken,-it may have been thought with less than the due respect to ny audience,of the popmlar theory.

59. Supposing that the octohedrous of gralena, of gold, and of oxide of iron, were endowed with powers of reproduction, and perished at appointed dates of discolution or solution, you wonld without am donbt have heard it by this time asserted that the octuherlic frim, which was common to all, indicated their descent from a commom 3 
progenitor; and it would hare been ingenionsly explained to you how the angular offspring of this eightsided ancestor had developed themselves, bT force of circnmstances, into their distinct metallic perfections; how the galena had become grey and brittle moler prolonged subterrancan heat,-and the gold yellow and ductile, as it was rolled among the pelbbles of amber-colonred streams.

60. Py the denial to these structures of any indirichually reproductive energy, you are forced to accept the inexplicable (and why expect it to be otherwise than inexplicable ?) fact, of the formation of a series of bodies having very similar aspects, qualities, and chemical relations to other substances, which ret have no connection whaterer with each other, and are goremed, in their relation with their native rocks, by entirely arbitrary laws. It has been the pride of modern chemistry to extricate herself from the ranity of the alchemist, and to admit, with resignation, the independent, though apparently fraternal, natmes, of silver, of lead, of platinum,-almminimm,-potassium. Hence, a rational philosophy would deduce the prohability that when the arborescence of dead crrstallization rose into the radiation of the living - tree, and sentient plume, the splendonr of natme in her more exalted power womld not be restricted to a less variety of design; and the beantifnl caprice in which she gave to the silver its frost, and to the opal its fire, would not he sublued under the slow inthences of accident and 
time, when she wreathed the swan with snow, and bathed the dore in iridescence. That the infinitely more exalted powers of life must exercise more intimate influence orer matter than the reckless forces of cohesion;-and that the loves and hatreds of the now conscions creatures would modify their forms into parallel beanty and degradation, we might have anticipated by reason, and we ought long since to have known by olserration. IBut this law of its spirit orer the substance of the creatmre inrulves, necessarily, the indistinctness of its type, and the existence of inferior and of higher conditions, which whole aras of heroism and affection-whole aras of misery and misconduct, confirm into glory, or confuse into shanne. Cullecting the canses of changed form, in lower creatmres, by distress, or by adaptation,-by the disturbance or intensifying of the parental strength, and the native fortune-the wonder is, not that species should sometimes be confused, but that the greater number of them remain so splendidly, so manifestly, so eternally distinct; and that the rile industries and ricions curiosities of modern science, while they have robbed the fields of Euglaud of a thonsand living creatures, have not created in them one.

61. But even in the paltry lnowledge we have obtained, what manimity have we? - what security? Suppose any man of ordinary sense, knowing the value of time, and the relative inportance of subjects of thought, and that the whole scientific world was agog concerning 
the origin of species, desired to know first of all-what was meant by a species.

He would naturally look for the definition of species first anong the higher animals, and expect it to be best defined in those which were best known. And being referred for satisfaction to the 226th page of the first volume of M[r. Darwin's "Descent of Man," he rould find this passage:-

"Man has been studied more carefully than any other organic leing, and yet there is the greatest possible diversity anomg apable judges, whether lie should be classed as a single species or race, or as two (Tirey), as three (Jacquinot), as four (Kant), five (Blumenbach), six (Buffon), seven (IInnter), eight (Agassiz), eleven (Pickering), fiftcen (Bory St. Vincent), sixteen (Desmonlins), twenty-two (Morton), sixty (Crawford), or as sixty-three aceording to Burke."

And in the meantine, while your men of science are thus vacillating. in the definition of the species of the only animal they have the opportmity of studying inside and ont, hetween one and sixty-three; and dispnting about the origin, in past ages, of what they cannot define in the flusent one; and deciphering the filthy licraldries which record the relation of hmmanity to the ascidian and the crocorlile, you have ceased ntterly to distingnish between the two species of man, evermore separate by infinite separation: of whom the one, capable of loyalty and of love, can at least conceive spiritnal natures which have no 
taint from their om, and leave behind them, diffused among thousinds on earth, the liappiness they never hoped, for themselves, in the skics: and the other, capable only of ararice, hatred, and slame, who in their lives are the companions of the swine, and leave in deatl nothing but food for the worm and the vulture.

6.2. Now I have first traced for you the relations of the crentme we are examining to those hencath it and above, to the lat and to the falcon. But you will find that it has still others to entirely another world. As you watch it glance and skim over the surface of the waters, has it never struck you what relation it bears to the creatures that glance and glide under their surface? Fly-catcher's, some of them, also,--fly-catchers in the same manner, with wide month; while in motion the lird almost exactly combines the dart of the tront with the dash of the dolphin, to the romnded forchead and projecting muzzle of which its own bullet head and bill exactly correspond. In its plunge, if yon watch it hathing, yon may see it dip its breast just as much nuder the water as a porpoise shows its back above. Tom can only rightly describe the bird by the resemblanres, and images of what it seems to lave rhanged from,--then arlding the fantastic and leantiful contrast of the mimaginable rhange. It is an owl that has been trained by the Cruces. It is a bat that loves the morning light. It is the aërial reflection of a dolphin. It is the tender domestication of a trout. 
63. And yet be assmred, as it cammot have been all these creatures, so it has nerer. in truth, been any of them. The transformations believed in by the mythologists are at least spiritually true; yon cannot too carefully trace or too accmately consider them. But the transformations believed in by the anatomist are as yet proved true in no single instance, and in no substance, spiritnal or naterial; and I camnot too often, or too earnestly, urge yon not to waste your time in guessing what animals may once have been, while you remain in nearly total ignorance of what thes are.

6t. Do yon even know distinctly from each other,(for that is the real naturalist's business; instead of confomding them with each other,,-do you linow distinctly the tive great species of this familiar bird? - the swallow, the honse-martin, the sand-martin, the swift, and the Alpine swift! - or can yom so much as answer the first question which would suggest itself to any carefirl observer of the form of its most familiar species,yet which I do not find proposed, far less answered, in any scientific book,-nanely, why a swallow has a swalJow-tail ?

It is true that the tail feathers in many birls appear to be entirely,-eren cumbronsly, decorative: as in the peacoek, and birds of paradise. Bnt I an confident that it is not so in the swallow, and that the forked tail, so defined in form and strong in plume. has indeed inportant func. tions in guiding the flight; yet notice how surrounded 
one is on all sides with pitfalls for the theorists. 'Tho forked tail reminds yon at ance of a tish's; and yot, the action of the two coreatures is wholly (oontrary. I fi-h lashes limself forwarl with his tail, and steer's with his fins; a swallow lashes himself forward with his fims, ambl steers with his tail; partly, mot necessurily, hecallece in the most dashing of the swallows, the swift, the fork of the tail is the least developerl. And I never watch the birl for a moment without finding myself in some fresh puzzle ont of which there is no che in the scientific: boulis. I want to know, for instance, how the bird turns. What does it do with one wing, what with the other? Fancy the pace that has to be stopled the forre of bridle-hand put ont in an instant. Fancy low the wings must lend with the strain; what need there must he for the perfect aid and work of every feather in them. There is a problen for you, stmdents of mechunic.s. - How A does a swallow turn?

Jou shall see, at all events, to begain with. to-dayy. how it gets along.

65. I say you shall see; bnt indeed you have often seen, and felt,--at least with your hands, if not with your shonlders.-when you chanced to be holding the sheet of a sail.

I have said that I never got into scrapes ly hlaming perple wongly; lut I often do by praining them wrongly. I nerer praised, withont qualification, Lut one scientific book in my life (that I renember) 一this of Dr. Petti- 
grew's on the Wing; *-and now I must qualify my praise considerably, discovering, when I examined the book farther, that the good doctor had described the motion of a bird as resembling that of a kite, withont ever inyniring what, in a bird, representer that somewhat important part of a kite, the string. Iou will, however, find the lrook full of important observations, and illustrated by valuable dramings. But the point in question you must settle for your-

* "On the Physiology of Wings." Transactions of the Royal Society of Eainburgh. Tol. xxvi., Part ii. I cannot sufficiently express either my wonder or regret at the petulance in which men of seience are continually tempted into immature jmblicity, by their rivalship with each other. Page after page of this book, which, slowly digested and taken counsel upon, might have bcen a noble contribution to natural history, is occupied with dimpute utterly useless to the reader, on the question of the priority of the anthor, by some months, to a French savant, in the statement of a principle which neither has yet proved; while page after page is rendered worse than useless to the reader by the author's lassionate endearour to contradict the ideas of unquestionably previons investigators. The problem of flight was, to all serious purpose, solved hy Torelli in $16 \mathrm{~s} 0$, and the following passage is very notable as an example of the way in which the endeavour to obscure the light ot former ages too fatally dims and distorts that by which modern men of science walk, themselves. "Borelli, and all who have written since his time, are ananimous in affirming that the horizontal transference of the body of the bird is due to the perpendicular vibration of the wings, and to the yielding of the posterior or flexible margins of the wings in an upward direction, as the wings descend. I" (Dr. Pettigrew) "am, however, disposed to attribute it to the fact (1st), that the rcings. both whon elevated and depressed, lecp) fomorrt. in curves, those curres uniting to form a continnous waved track; (2nd), to the tendency which the brdy of the bird has to swing fordurds, in a more or less horizontal direction, elen once set in motion; ( $3 \mathrm{rd}$, to the construction of the wings; they are elastic helices or screws, which twist and nntwist while they vibrate, and tend to bear nquoreds and onumeds any areight suspondel from them; (4th), to the reaction of the air on the under sur- 
selves, and you easily may. Some of you, perliaps, knew, in your time, better than the doctor, how a kite stopled; but I do not dombt that a ganeat many of you also kinow, 1001, what is much more to the purpese, how a ship gets along. I will take tlue simplest, the most natural, the most beautiful of sails, - the lateen sail of the Mediterranean.

66;. I draw it rudely in outline, as it would be set for a side-wind on the buat you probalsly know best, - the hoat

fuces of the wings; (5) th), to the ever-varying pores with which the wings are urged, this being greatest at the beginning of the down-stroke, and least at the end of the up one; (6th), to the contruction of the voluntary musctrs and elastic ligaments, and to the effect produced by the various inclined surfaces formed by the wings during their oscillations; (\%th), to the acright of the bird-weight itself, when acting upon wings, becoming a propelling power, and so contributing to horizontal motion."

I will collect these seren reasons for the forward motion, in the gist of them, which I have marked by italics, that the reader may better judge of their collective value. The bird is carricd forward, according to Dr. Pettigrew-

1. Because its wings leap forward.

2. Because its body has a tendency to swing folward.

3. Because the wings are screws so constructed as to screw upwards and onwards any body su-pended from them.

4. Because the air reacts on the under surfaces of the wings.

5. Because the wings are urged with erer-varying power.

6. Because the roluntary muscles contract.

\%. Because the bird is heary.

What must be the general conditions of modem science, when it is possible for a man of great experimental knowledge and practical ingenuity, to publish nonsense such as this, becoming, to all intents and purposes, iusane, in the passion of his endlavour to orerthrow the statements of his rival? Had he merely taken patience to consult any elementary scholar in dymamics, he would have been cuabled to understand his own machines, and develope, with credit to himself, what had been rightly judged or noticed by others. 
of brrden on the Lake of Genera (Fig. 3), not confusing the drawing by adding the mast, which, you know, rakes a little, carrying the yard across it. (u). Then, with your permission, I will load my boat thms, with a few casks of FIG. 3.

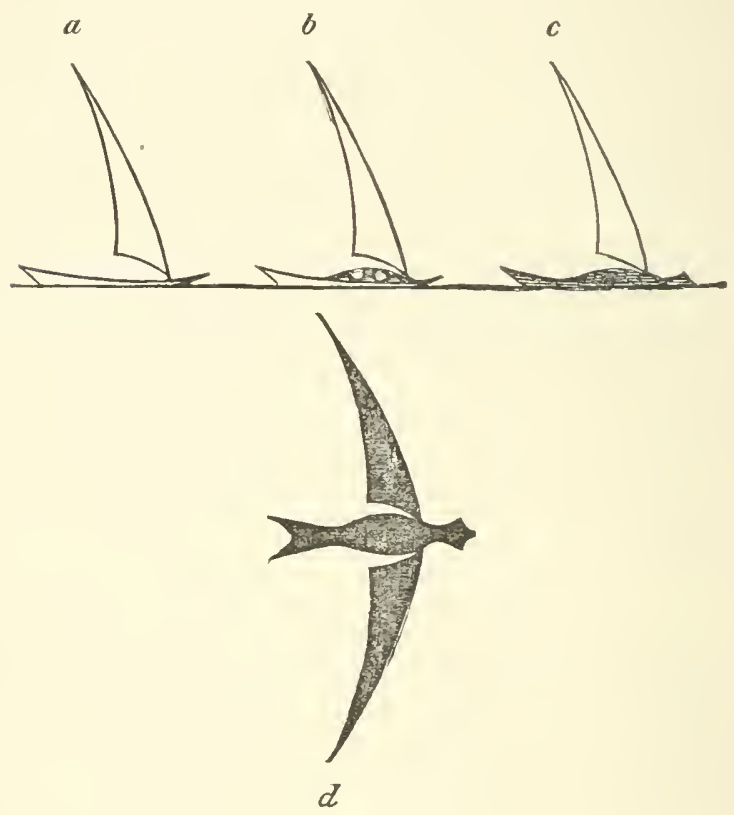

Teray vintage-and, to keep them cool, we will put an awning over them, so (b). Next, as we are classical scholars, instead of this rustic stem of the boat, meant ouly to run easily on a flat shore. we will give it an ittic $\epsilon \mu \beta o \lambda o v(c)$. (We have no husiness, indeed, yet, to put an 


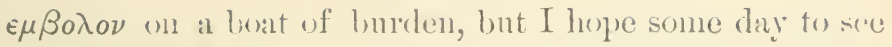
all our ships of watr loaded with breat and wine, instead of artillery.) Then I sharle the entire form (r); and, lastly, reflect it in the water. $(d)$-and you have seen something like that before, besides a brat. havenit you?

There is the gist of the whole business for you, put in very small space; with these only differences: in a boat, the air strikes the sail; in a bird, the sail strikes the air: in a boat, the force is latelal, and in a bird downwarks; and it has its sail on both sides. I shall leave yon to follow out the mechanical problem for yourselves, as far as the mere resolution of foree is concener. My business, as a painter, is only with the exquisite organic weapon that deals with it.

6\%. Of which you are now to note farther, that a lirel is required to manage his wing so as to oltain two results with one blow:-lhe has to keep himself "1), as well as to get along.

But olserve, he only requires to keep himsolf up because he has to get along. The hnoyanry might have been given at once, if nature lad wanted that only; she might have blown the feathers up with the hot air of the breatl, till the bird rose in air like a cork in water. IBnt it has to be, not a buoyaut cork, but a buoyant bullet. And therefore that it may have momentmm for pace, it must have weight to earry ; and to carry that weight, the wings must deliver their blow with effective rertical, as rell as oblique, force. 
Here, again, you may take the matter in brief sum. Whaterer is the ship's loss, is the bird's gain; whaterer. tendency the ship has to leerray, is all given to the bird's smpport, so that every atom * of force in the blow is of service.

68. Therefore you have to construct your organic weapon, so that this absolntely and perfectly economized force may be distributed as the bird chooses at any moment. That, if it wants to rise, it may be able to strike vertically more than obliquely;--if the order is, go a-head, that it may put the oblique screw on. If it wants to stop in an instant, that it may be able to throw its wings up full to the wind; if it wants to hover, that it may be able to lay itself quietly on the wind with its wings and tail, or, in caln air, to regnlate their vibration and expansion into tranquillity of gliding, or of pansing power. Given the varions proportions of weight and wing; the conditions of possible increase of muscular furce and quillstrength in proportion to size; and the different ohjects and eiremmstances of flight,- - yon hare a series of exquisitely complex problems, and exquisitely perfect solutions, which the life of the youngest among yon tamnot be long enough to read throngh so much as once, and of which the future infinitudes of hmman life, howerer granted or extended, never will be fatigned in admiration.

* I don't know what word to use for an infinitesimal degree or dirided portion of force: one can't properly speak of a force being cut into pieces; but I can think of no other word than atom. 
69. I take the rude ontline of sail in Fig. :, and nuw considering it as a jil of one of on own sailing resels, slightly exaggerate the loops at the eclge, and diaw enred lines from them to the opposite point, Fig. 4 ; and

FIG, 4.

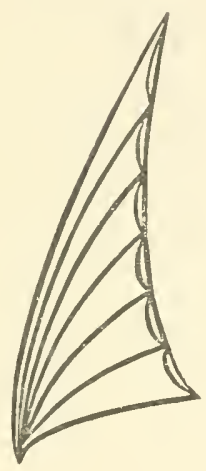

I have a reptilian or dragon's wing, which wonld, with some ramification of the supporting ribs, become a bat's or moth's; that is to say, an extension of membrane between the ribs (as in an nmbrella), which will catch the wind, and flutter upon it, like a leaf; but cannot strike it, to any purpose. The flying squirrel drifts like a falling leaf; the bat flits like a llack rag torn at the edge. To give power, we must have plumes that can strike, as witl the flat of a sword-blade; and to gire pufect power, these must be laid orer each otlier, so that each may support the one below it. I use the word below advisedly: we have to strike down. The lowest feather is the one that 
first meets the adverse force. It is the one to be supported.

Now for the manner of the support. Fon must all linuw well the look of the machicolated parapets in meeliaval castles. Yon know they are carried on rows of small projecting buttresses constructed so that, thongh the uppermust stone, far-projecting, wonld break easily under any shock, it is supported by the next below, and so on, down to the wall. Now in this fignre I am obliged to separate the feathers by white spaces, to show you them distinctly. In reality they are set as close to each other as can be, but putting them as close as I can, you get $a$ or b, Fig. 5, for the rough section of the wing, thick torards the bird's heal, and curved like a sickle, so that in striking down it catches the air. like a reaping-hook, and in rising ${ }_{1}$, it throws off the air like a pent-honse.

70. The stroke wonld therefore be rigorons, and the recorery alnost effortless, were eren the direction of both actually vertical. But they are vertical only with relation to the bird's body. In space they follow the forrard flight, in a softly curved line; the downward struke being as effective as the bird chooses, the recorery scarcely encounters resistance in the softly gliding ascent. Thus, in Fig. 5, (I can only explain this to readers a little verserl in the elements of mechanics, ) if $\mathrm{I}$ is the locus of the centre of gravity of the bird, moving in slow flight in the direction of the arrors, $w$ is the locns of the leading feather of its wing, and $u$ and b, ronghly, the succes- 
sive positions of the wing in the down-stroke and recovery.

FIG. 5.

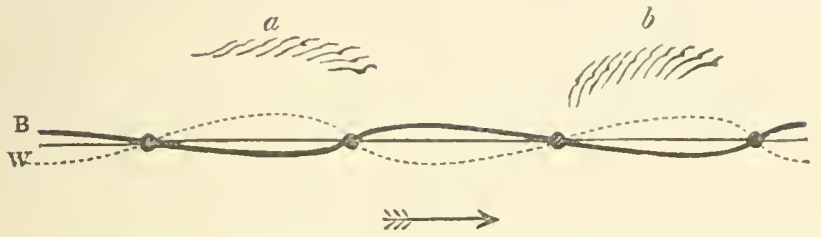

71. I say the domn-stroke is as effective as the bird chooses; that is to say, it can le given with exactly the quantity of impulse, and exactly the quantity of supporting power, required at the moment. 'Thus, when the bind wants to Hy slowly, the wings are fluttered fast, giving rertical blows; if it wants to panse absolutely in still air, (this large birds cannot do, not being able to more their wings fast enough.) the relocity becomes viluation, as in the humming bird: but if there is wind, any of the larger lirds ean lay themselves on it like a kite, their own weight answering the purpose of the string, while they keep the wings and tail in an inclined plane, giving them as much gliding ascent as comnteracts the fall. They nearly all, howerer, nse some slightly gliding force at the same time; a single stroke of the wing, with forward intent, seeming enough to enable them to glide on for half a minnte or more withont stirring a plume. A circling eagle floats an inconceivable time without risible stroke: (fancy the pretty action of the inner wing, bucking air instead of water, which 
gives exactly the lrearth of circle he chooses). But for exhibition of the complete art of flight, a swallow on romgh water is the master of masters. A seagull, with all its splendid power, generally has its work cut out for it, and is visibly tighting; but the swallow plays with wind and wave as a girl plays with her fan, and there are no words to say how many things it does with its wings in any ten seconds, and does consmmmately. 'The mystery of its dart remains alwars inexplicable to me; no eve can trace the bending of bow that sends that living arrow.

But the main structure of the noble weapon we may with little pains mulerstand.

72. In the sections $a$ and $b$ of Fig. 5, I have only represented the quills of the onter part of the wing. The relation of these, and of the inmer quills, to the bird's body nay be very simply shown.

Fig. 6 is a rude sketch, typically representing the wing of any birl, but actually founded chietly on the seagnll's.

It is broadly composed of two fans, $A$ and $s$. The outmost fan, $\Lambda$, is carried by the bird's hand; of which I midely sketch the contour of the bones at $a$. The innermost fan, B, is carried by the bird's fure-arm, from wrist to elbow, $b$.

The strong humerus, $c$, corresponding to our arm from shonlder to elbow, has command of the whole instrument. No feathers are attached to this bone; but corering and protecting ones are set in the skin of it, completcly filling, 
when the active wing is open, the space between it and the body. Bnt the plumes of the two gyleat fans, 1 and s, are set into the bones; in Fig. s, firther on, are

FIG. 6.

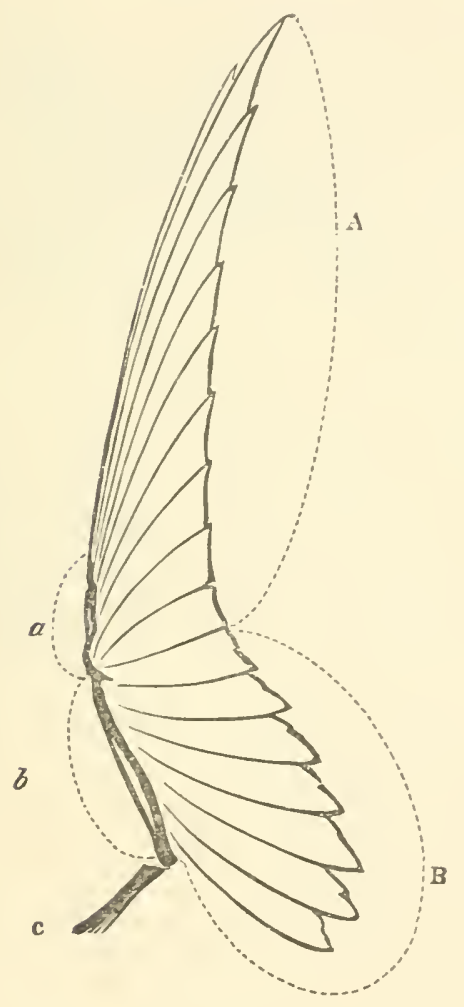

shown the projecting knobs on the main arm bone, set for the reception of the quills, which make it look like the 
club of Ilercules. The connection of the still more powerful quills of the outer fan with the bones of the hand is quite beyond all my poor anatomical perceptions, and, happily for me, also beyond needs of artistic investigation.

73. The feathers of the fan $A$ are called the primaries. Those of the fan $\mathrm{B}$, secondaries. Effective actions of flight, whether for support or forward motion, are, I believe, all executed with the primaries, every one of which may be briefly described as the strongest scrmatar that can be made of quill snbstance; flexible within limits, and elastic at its edges-carried by an elastic central shaft_twisted like a windmill sail — striking with the flat, and recovering with the edge.

The secondary feathers are more romiled at the ends, and frequently notched; their currature is reversed to that of the primaries; they are arranged, when expanded, somewhat in the shape of a shallow enp, with the hollow of it downwards, loblding the air therefore, and aiding in all the pause and bnorancy of flight, but little in the activity of it. Essentially they are the brooding and covering feathers of the wing; expmisitely beantiful-as far as I have yet seen, most beautifnl-in the bird whose hrooding is of most nse to us; and which has become the image of all tenderness. "How often would I have gathered thy children . . . and ye would not."

74. Orer these two chief masses of the plume are set others which partly complete their power, partly adorn 
and protect them; but of these I can take no nutice at present. All that I want you to molerstand is the action of the two main masses, as the wing is opened and closed

FIG. 7.

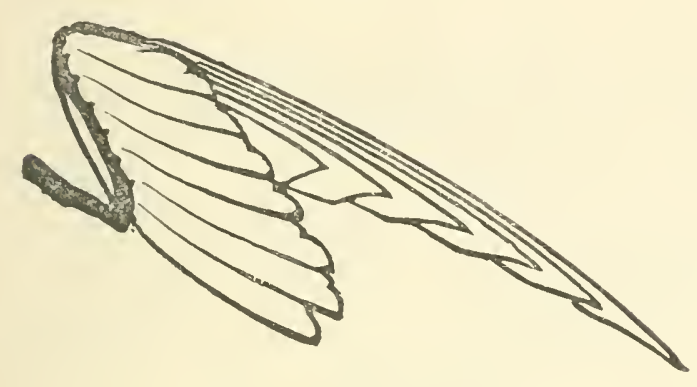

Fig. 7 roughly represents the upper surface of the main feathers of the wing closed. The secondaries are folded over the primaries; and the primaries shut np) close, with their onter edges parallel, or nearly so. Fin. s roughly shows the outline of the bones, in this position, of one of the larger pigeons.*

75. Then Fig. 9 is (always sketched in the romghest way) the outer, Fig. 10 the imer, surface of a scugull's wing in this position. Next, Fig. 11 slowes the tops of the four lowest feathers in Fig. 9, in mere ontline; A separate (pulled off, so that they can be set side hy side), B shut up close in the folded wing, c opened in the spread wing.

* I find even this mere outline of anatomical structure so interfere with the temper in which I wish my readers to thiuk, that I shall withdraw it in my complete edition. 
7f. And now, if rou will yourselves watch a few birds in flight. or opening and closing their wings to prune then, ron will soon know as much as is needful for onr

FIG. 8.

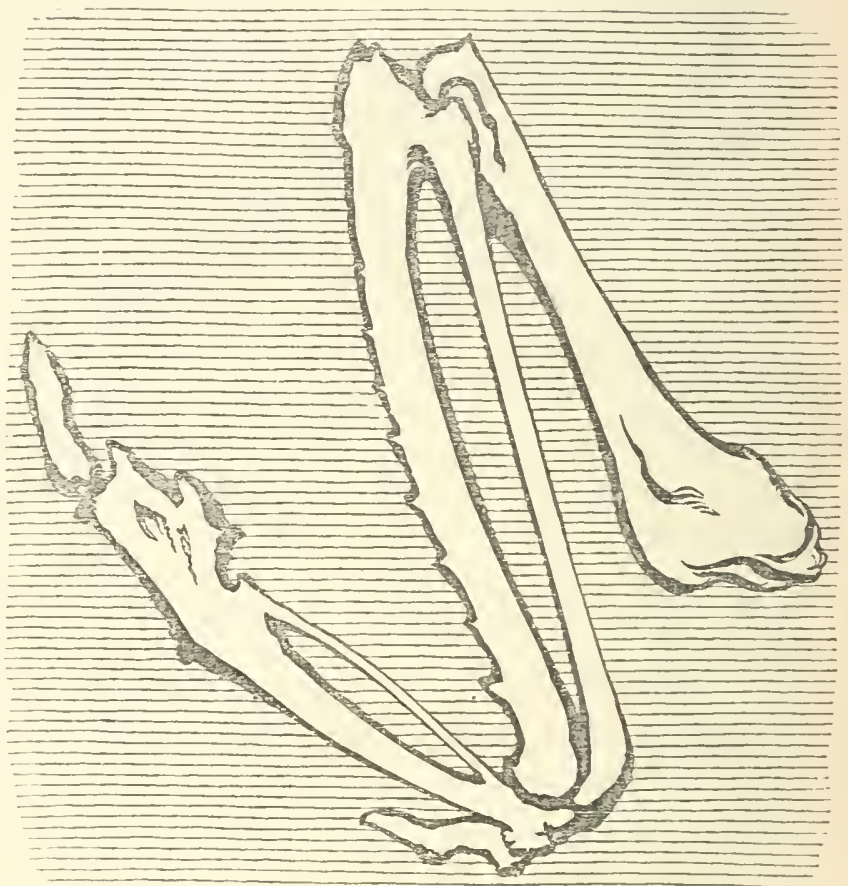

art purposes; and, which is far more desirable, feel how very little we know, to any purpose, of eren the familiar creatures that are our companions. 
Even what we have seen to-day * is more than appears to have been moticed by the most careful painters of the erreat schools; and you will continually fancer that I am inconsistent with myself in pressing you to learn, bettel than they, the anatomy of bidels, while I violently and constantly urge you to refuse the kmowledge of the anatomy of men. But you will find, as ny system developes itself, that it is absolntely consistent thromghont. I don't

FIG, 9.

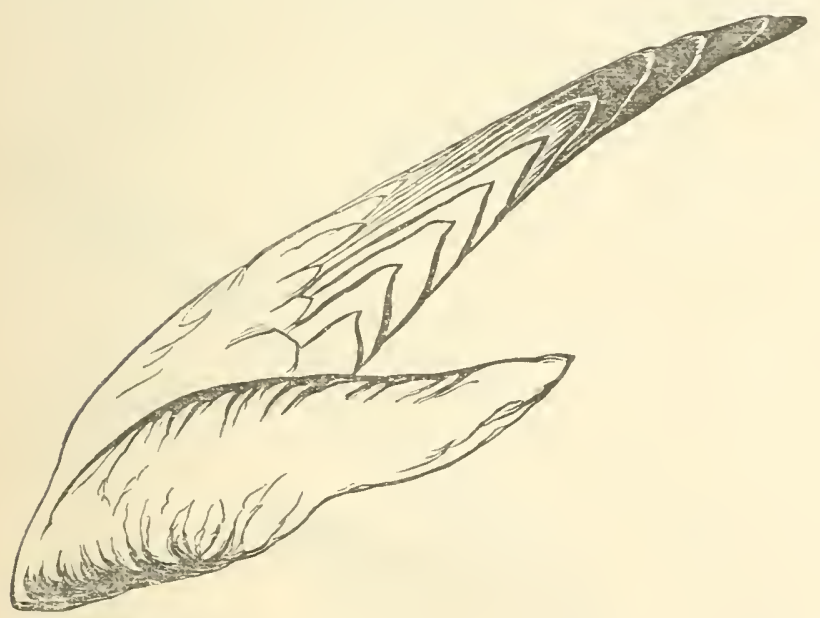

mean, by telling you not to stndy hmman anatomy, that you are not to know how many fingers and toes you hare, nor how you wan grasp and walk with them : and. sini-

* Large and somewhat carefully painted diagrams were shown at the lecture, which I cannot engrave but for my complete edition. 
larly, when you look at a bird, I wish you to know how many claws and wing-feathers it has, and how it grips and flies with them. Of the bones, in either, I shall show you little; and of the muscles, nothing but what can be seen in the living creature, nor, often, eren so much.

77. And accordingly, when I now show you this sketch of my farourite Ilolbein, and tell you that it is entirely disgraceful he should not know what a wing was, better, -I don't mean that it is discraceful he should not know the anatomy of it, but that he shonld nerer have looked at it to see how the feathers lie.

FIG, 10 ,

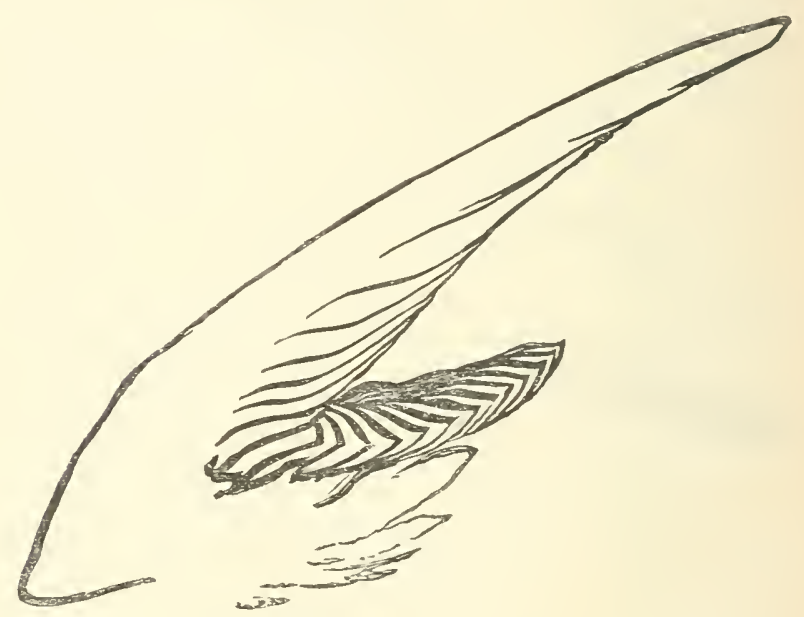

Now Iolbein paints men glorionsly. but nerer looks at birds; Gibbons, the woodentter, carres birds, but 
can't men;--of the two fanlts the last is the worst; but FIG. 11.

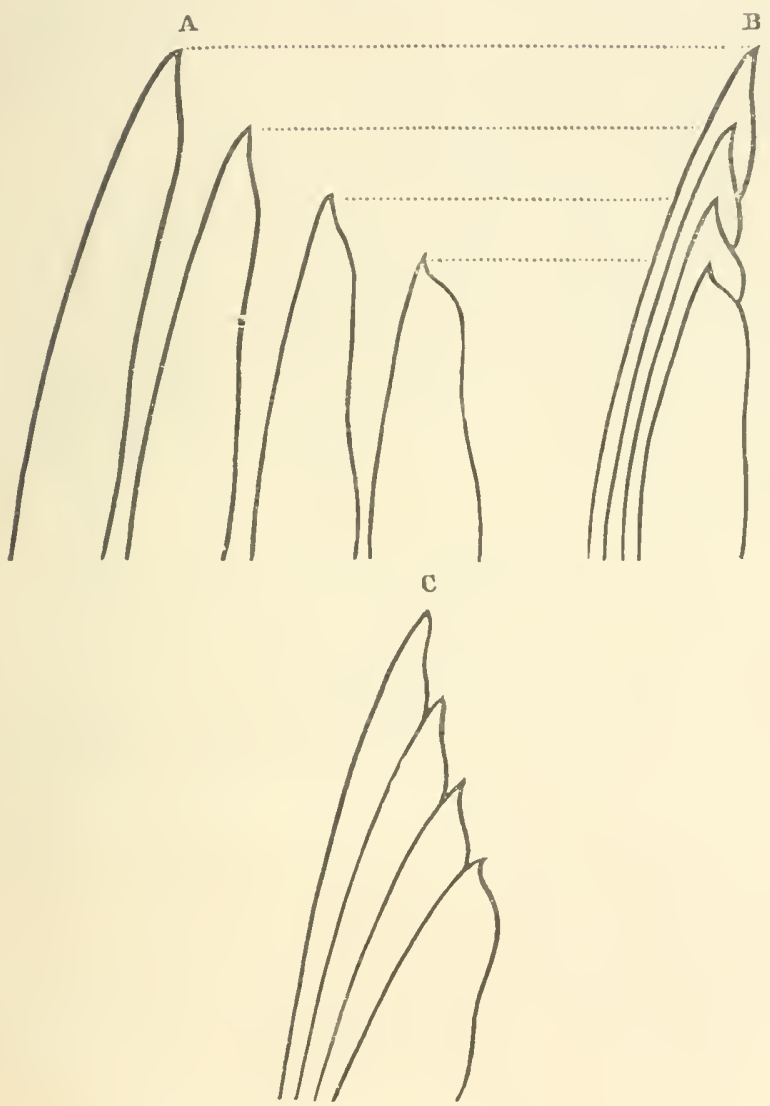

the right is in looking at the whole of nature in due comparison, and with miversal candomr and temlemess. 
75. At the whole of nature, I sar, not at super-nature -at what ron suppose to be above the risible nature abont yon. If yon are not inclined to look at the wings of birds, which God has giren ron to handle and to see, much less are you to contemplate, or draw inaginations of, the wings of angels, which you can't see. Finow your own world first-not denving any other, but being quite sure that the place in which you are now put is the place with which yon are now concemed; and that it will be wiser in yon to think the gods themselves may appear in the form of a dove, or a swallow, than that, by false theft from the form of dove or swallow; ron can represent the aspect of gods.

79. One sweet instance of such simple conception, in the end of the Odyssey, must surely recur to your mints in comnection with onr subject of to-day, but you may not have noticed the recurent manner in which IIomer insists on the thonght. When L lyses first bends and strings his bow, the ribration of the chord is shrill, "like the note of a swallow." A poor and unwarlike simile, it seems! But in the next hook, when Llysses stands with his bow lifted, and Telemachus has buonght the lances. and laid them at his feet, and Athena comes to his side to enconrage him,-do you recollect the gist of her speech? "Ton fonght," she sars, "nine rears for the sake of Telen, and for another's house:-now, retmrned, after all those wanderings, and under your own roof, for it, and its treasures, will ron not fight, then?" And she herself 
flies up to the homier-rouf, and thence, in the' firm, of the sucullow, gaides the arrows of rengeance for the violation of the sanctities of home.

so. 'To-day, then. I believe verily for the first time, I have been able to put before you some neans of gnidance to understant the heanty of the hird which lives with you in your own honses, and which purifies for yon, from its insect pestilence, the air that you breathe. Thus the sweet domestic thing has done, fir men, at least these fomr thonsand years. She has been their companion, not of the home nerely, but of the hearth, and the threshold; companion only endeared by departure, and showing better her loring-kindness by her faithful return. Type sometines of the stranger, she has softened us to hospitality; trpe alwars of the suppliant, she has enchanted us to merey: and in her feehle mesence. the cowardice, or the wrath, of sacrilege has changed into the tidelities of sanctuary. Herald of our summer, she glances through our days of glarlness; nmmberer of onr rears, she would teach us to apply om hearts to wislom;--and yet, so little have we regarded her, that this rery day, scarcely able to gather from all I can tind told of her enongh to explain so much as the unfolling of her wings, I can tell you nothing of her life-nothing of her jonmeying: I "annot leam how she builds, nor how she rhonses the place of her wandering. non how she traces lle path of loes return. Remaining thus blind and careles to the true ministrics of the humble creatme whom God has really 4 
sent to serre us, we in our pride, thinking ourselves surromnded by the pursuivants of the sky, can yet only inrest them with majesty by giving them the calm of the bird's motion, and shade of the bird's plume:-and after all, it is well for us, if, when even for God's best nercies, and in His temples marble-built, we think that, "with angels and archangels, and all the company of Hearen, we land and magnify His glorions name" - mell for ns, if omr attempt be not only an insult. and His ears open rather to the inarticulate and unintended praise, of "the Swallow, twittering from her straw-built shed." 
• 




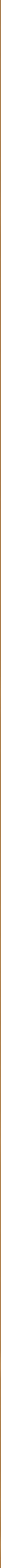



QL Ruskin, John

676 Love's meinie

R87

BioMed

PLEASE DO NOT REMOVE

CARDS OR SLIPS FROM THIS POCKET

\section{UNIVERSITY OF TORONTO LIBRARY}


